This PDF is a selection from a published volume from the National Bureau of Economic Research

Volume Title: Reforming the Welfare State: Recovery and Beyond in Sweden

Volume Author/Editor: Richard B. Freeman, Birgitta Swedenborg and Robert Topel, editors

Volume Publisher: The University of Chicago Press

Volume ISBN: 0-226-26192-1

Volume URL: http://www.nber.org/books/free05-1

Conference Dates: September 30-October 1, 2005

Publication Date: February 2010

Chapter Title: Did Active Labor Market Policies Help Sweden Rebound from the Depression of the Early 1990s?

Chapter Author: Anders Forslund, Alan Krueger

Chapter URL: http://www.nber.org/chapters/c5362

Chapter pages in book: (159 - 187) 


\title{
Did Active Labor Market Policies Help Sweden Rebound from the Depression of the Early 1990s?
}

\author{
Anders Forslund and Alan Krueger
}

\subsection{Introduction}

In the early 1990s, the Swedish labor market was hit by the worst shock it had experienced since the 1930s, with the unemployment rate rising to 10 percent. This development stands out in light of Sweden's performance in the postwar period. Between the mid-1940s and the crisis of the 1990s, the Swedish unemployment rate oscillated between 1 percent and just under 4 percent (figure 5.1). Unemployment even remained low in the 1970s, despite oil price shocks that led to persistently high unemployment elsewhere in Europe. A natural question is, what, if anything, in Swedish institutions and policies explains why Sweden's unemployment rate did not follow the same pattern as in most Western European countries? A factor often mentioned for this envious performance is Sweden's active labor market policies (ALMPs; e.g., cf. Layard, Nickell, and Jackman 1991).

The United States also avoided the persistently high unemployment rates of the Western European countries. Admittedly, the U.S. unemployment rate rose at about the same time as in Western Europe during the downturns of the 1970s and early 1980s. However, it also declined rapidly as the business cycle improved. The U.S. unemployment rate has also been lower than Sweden's during most years since the early 1990s. A common explanation of the more favorable development in the United States was its flexible labor market and modest social safety net, giving rise to high job search intensity, lower reservation wages,

Anders Forslund is the assistant director-general and an associate professor at the Institute for Labor Market Policy Evaluation. Alan Krueger is the Bendheim Professor of Economics and Public Affairs at Princeton University and a research associate of the National Bureau of Economic Research. 


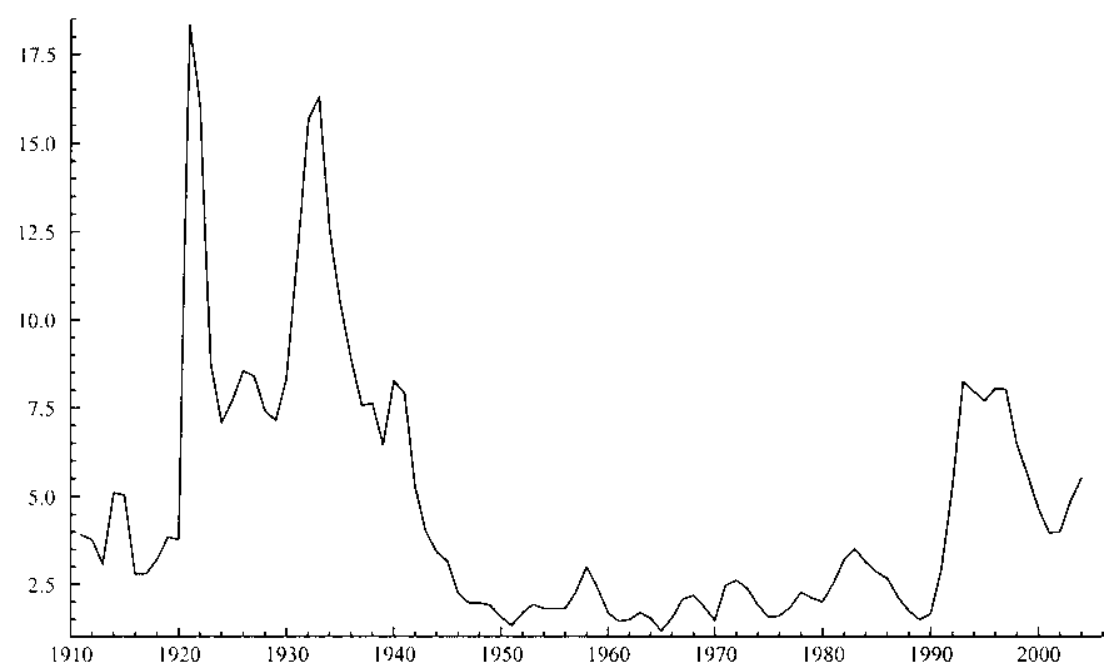

Fig. 5.1 Swedish unemployment, 1911 to 2004, share of the labor force (\%)

Note: 1911 to 1955: unemployed union members; 1955 to 1961: unemployed registered at the Public Employment Service; 1961 to 2004: Statistics Sweden, labor force surveys.

and consequently, to considerably shorter unemployment spells than in Europe.

The steep increase in unemployment in Sweden did not reflect in any obvious way a reduced commitment to ALMPs (see figure 5.2). Extensive ALMPs, however, could not prevent the Swedish unemployment rate from rising in the early 1990s. Yet, this was not unexpected - the rapid increase in unemployment primarily reflected a rapid increase of the inflow into unemployment that could not reasonably be prevented by ALMPs.

In a previous paper (Forslund and Krueger 1997), we questioned whether ALMPs actually could have been a main explanation of the earlier low levels of unemployment. We showed that the scientific support for the view that ALMPs had played a key role in keeping Swedish unemployment low was fragile. We found that relief work crowded out regular jobs in some sectors (so that the net effect on unemployment was considerably smaller than the number of program participants). We also found that the evidence from cross-country studies of the kind that Layard, Nickell and, Jackman (1991) used to support the view that large-scale ALMPs lead to lower unemployment rates was not robust to the time period studied. Furthermore, it was hard to argue that the benefits of labor market training were large enough to offset the high costs. We also voiced concern that the generous social safety net and ALMPs in Sweden could lead to hysteresis. Indeed, to an outsider, it was puzzling that Sweden was able to maintain such low unemployment as it did before 1991 with its generous benefits for the nonemployed. Presumably, social stigma discouraged excessive use of public programs. We feared that 


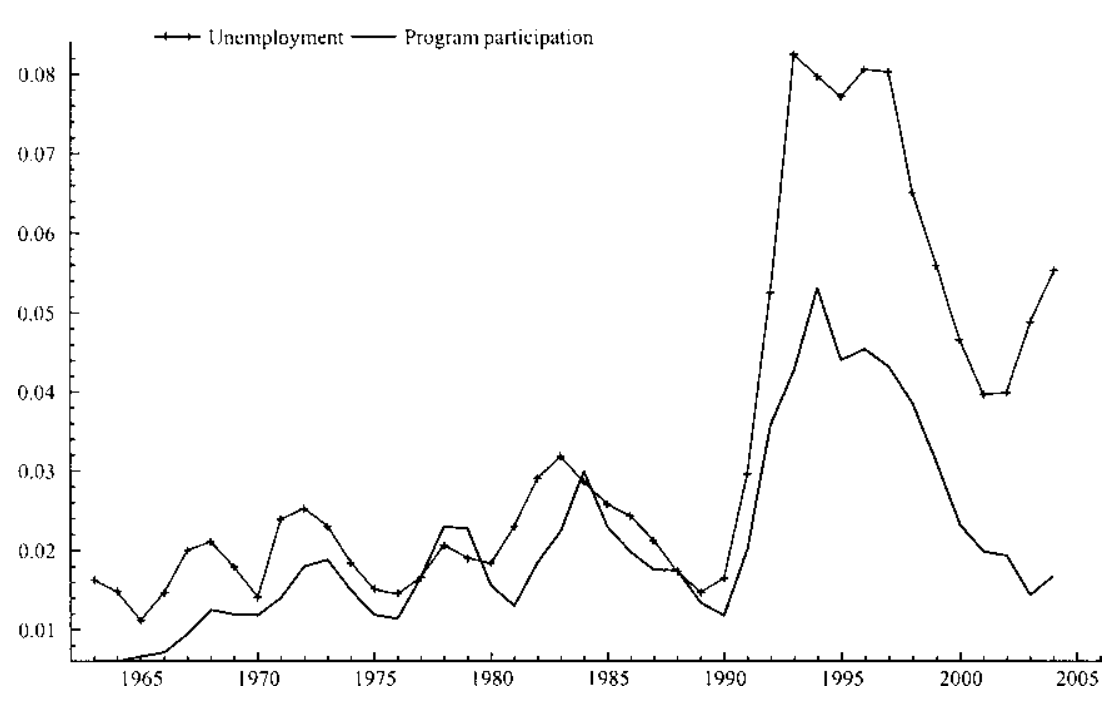

Fig. 5.2 Unemployment and program participation, 1963 to 2004 (shares of labor force)

this stigma could erode as a result of widespread unemployment in which weakness in the overall economy rather than shortcomings in individual initiative could be blamed for unemployment, leading to greater reliance on social benefits and ALMPs for years to come. At the same time, we did not find any obvious signs that the Swedish labor market suddenly worked less well and that this could explain the high unemployment rate of the early 1990s.

The fact that ALMPs were not sufficient to prevent the crisis of the early 1990s and that they probably were not important for the previous low unemployment rates does not imply that they were ineffective at combating the unemployment crisis of the 1990s.

Hence, in the following, we investigate whether ALMPs facilitated the recovery from the high unemployment rates of the early 1990s. To remove all suspense, we conclude that ALMPs probably played a minimal role in reducing total unemployment since the early 1990s. Although the programs may have maintained high labor force attachment, unemployment was slow to decline compared with past shocks, and cycling through programs and participation in unemployment insurance (UI) was common. The main function of ALMPs has been to cushion the blow of unemployment for those who become unemployed, not to speed reemployment or to increase overall employment. While the former is clearly important and salutary, interest in finding a combination of policies to raise employment remains high. Indeed, Sweden's commitment to supporting the unemployed and to reforming the mix of ALMPs when they do not seem to be as efficient as 
possible is admirable. The optimal formula, however, appears to be a work in progress.

\subsection{The Swedish Labor Market Since the Early 1990s}

In figure 5.2, we saw that the Swedish unemployment rate increased very rapidly between 1990 and 1993, from 1.5 percent to just above 8 percent, or from just under 3 percent to fully 13 percent as measured by total unemployment (the sum of open unemployment and program participation). Subsequently, the unemployment rate remained high until the business cycle upturn of the late 1990s. The decrease in unemployment was rapid, but by the time the unemployment rate increased again in 2003, it had never dropped below approximately 4 percent, twice the level of typical business cycle peaks during the decades preceding the 1990s. This could indicate a change for the worse in the workings of the Swedish labor market since the 1980s.

As we have already pointed out, the rise in unemployment was accompanied by a rapid increase in participation in labor market programs; in the mid-1990s, program participation amounted to around 5 percent of the labor force (figure 5.2).

Although dramatic, the increase in unemployment and program participation actually downplays the magnitude of the shock to the Swedish labor market. This is clear from figure 5.3, figure 5.4, and figure 5.5, where the evolution of labor force participation and employment in Sweden is compared with that in the United States.

The steep increase in unemployment reflected both an increased inflow and a longer duration (figure 5.6) of unemployment spells. Indeed, inflow and duration covary quite closely from the early 1990s on.

The observation that unemployment rates have not fallen to the pre-1990s levels may indicate deterioration in the functioning of the Swedish labor market. A common way to diagnose such problems is to examine the Beveridge curve - the relationship between vacancies and unemployment - for outward shifts. In Forslund and Krueger (1997), we concluded that there were no signs of a significant outward shift of the Swedish Beveridge curve over the period from 1981 to 1991; on the contrary, we detected a significant inward shift.

Looking at more recent data, there possibly may be an outward shift of the Beveridge curve, both in terms of open unemployment (figure 5.7) and in terms of total unemployment (figure 5.8). This impression is also supported by a more formal analysis. We estimated Beveridge curves using data for the period from 1970 to 2004, and an included time trend was significant and positive, confirming the visual impression from the plots. In a bookkeeping sense, this shift probably reflects the increased inflow into unemployment displayed in figure 5.6. 


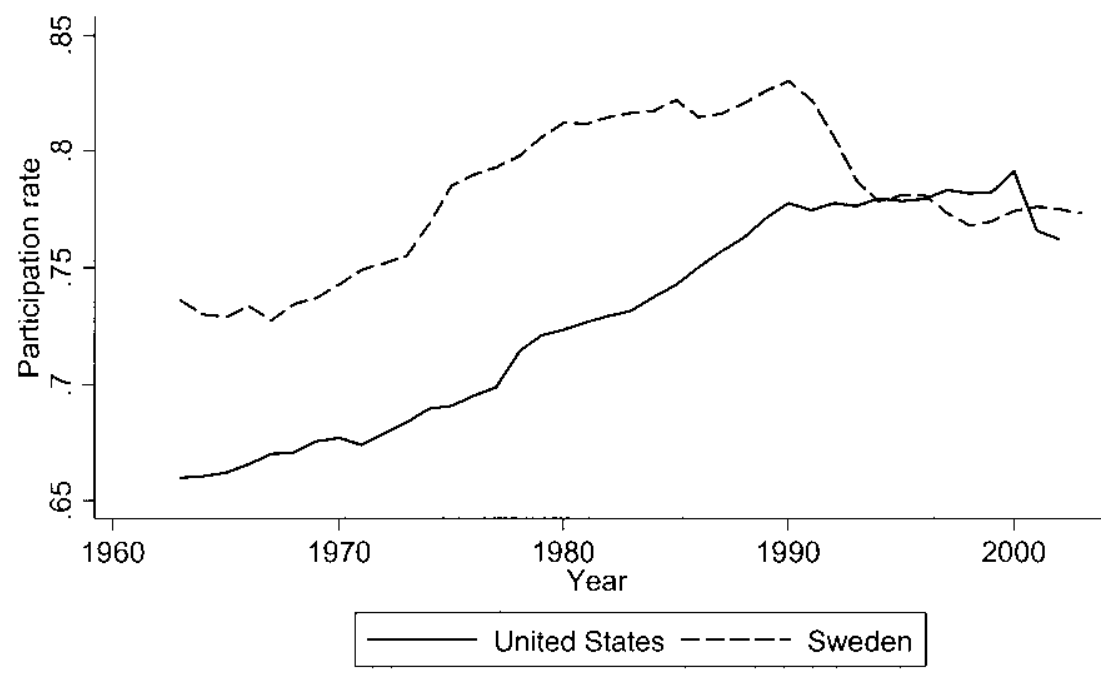

Fig. 5.3 Labor force participation in Sweden and the United States, 1963 to 2003 (share of population in active ages)

Source: OECD labor force statistics.

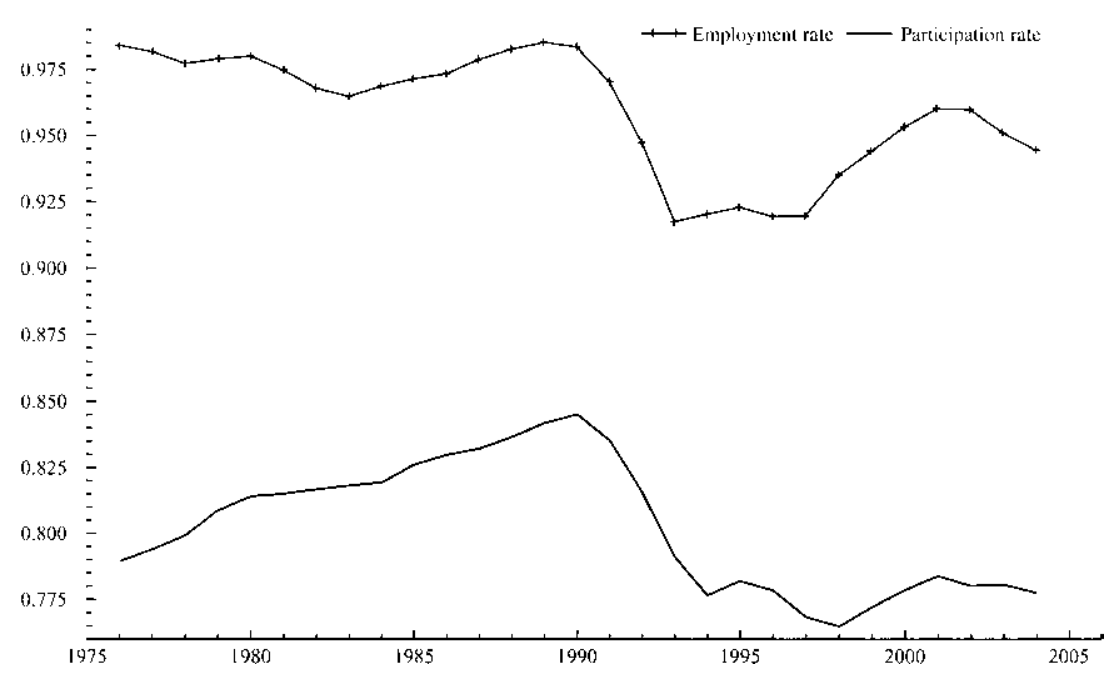

Fig. 5.4 Employment relative to labor force and labor force participation rate in Sweden, 1976 to 2004

Source: Statistics Sweden, labor force surveys. 


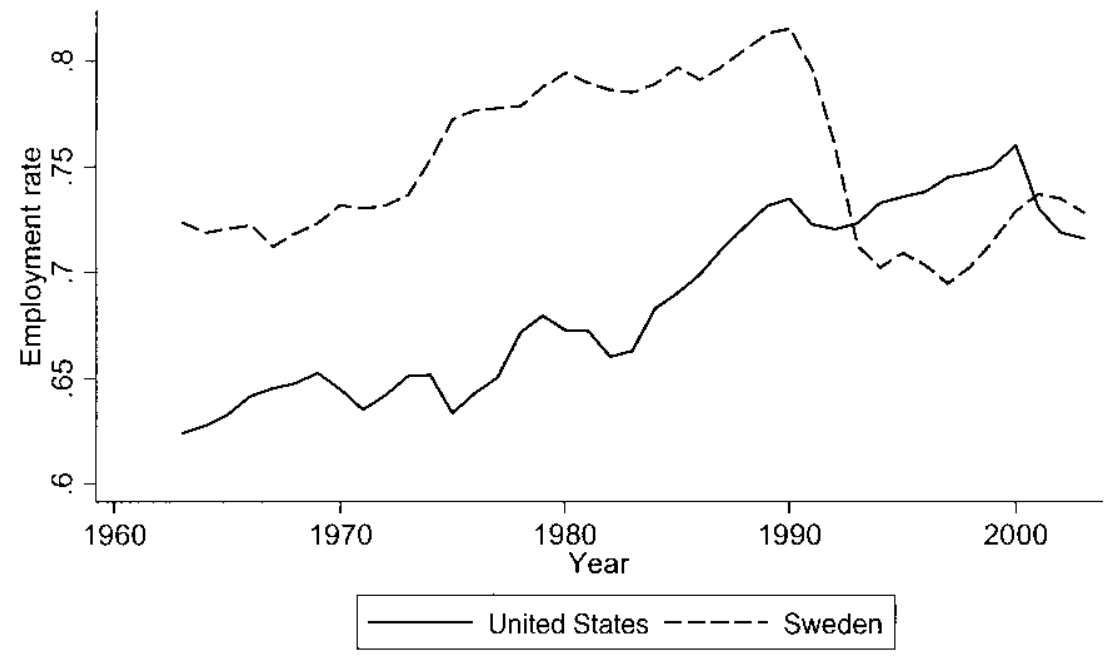

Fig. 5.5 Employment-to-population rate, 1963 to 2003, in Sweden and the United States (share of active population)

Source: OECD labor force statistics.

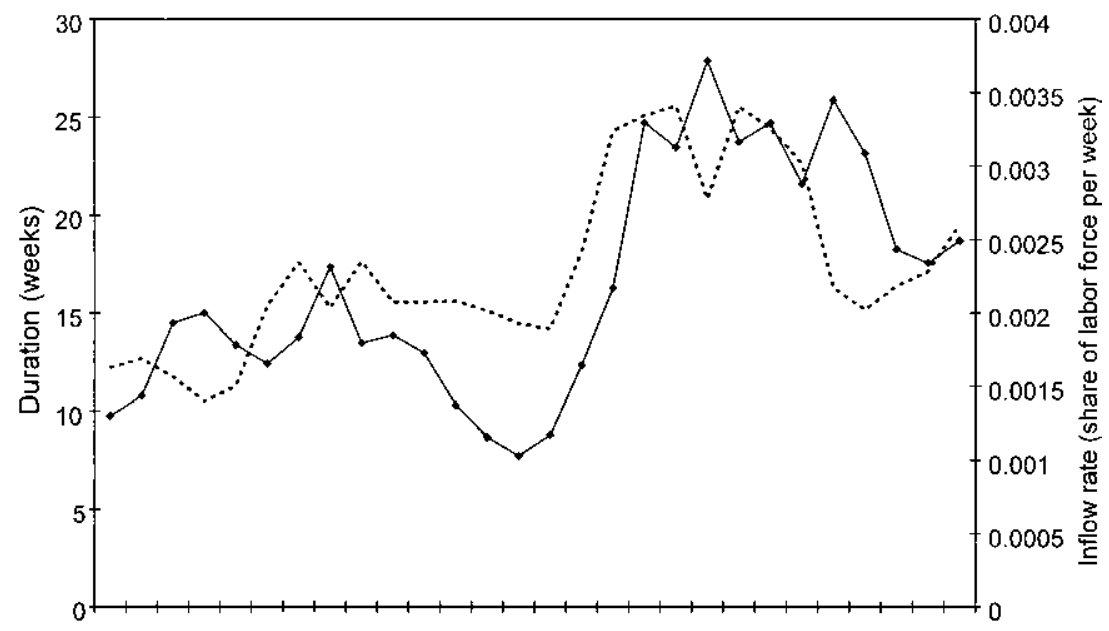

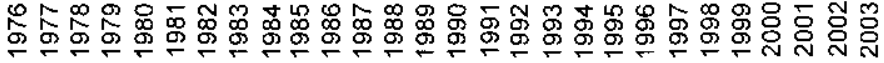

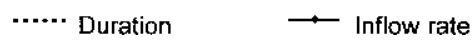

Fig. 5.6 Inflow to unemployment (right-hand scale) and the duration of unemployment (left-hand scale), 1972 to 2002, aged sixteen to sixty-four years

Source: Computations by Bertil Holmlund based on Labor Force Survey data.

Note: The inflow is given as weekly inflow as a share of the labor force (\%). The values are running three-year averages. 


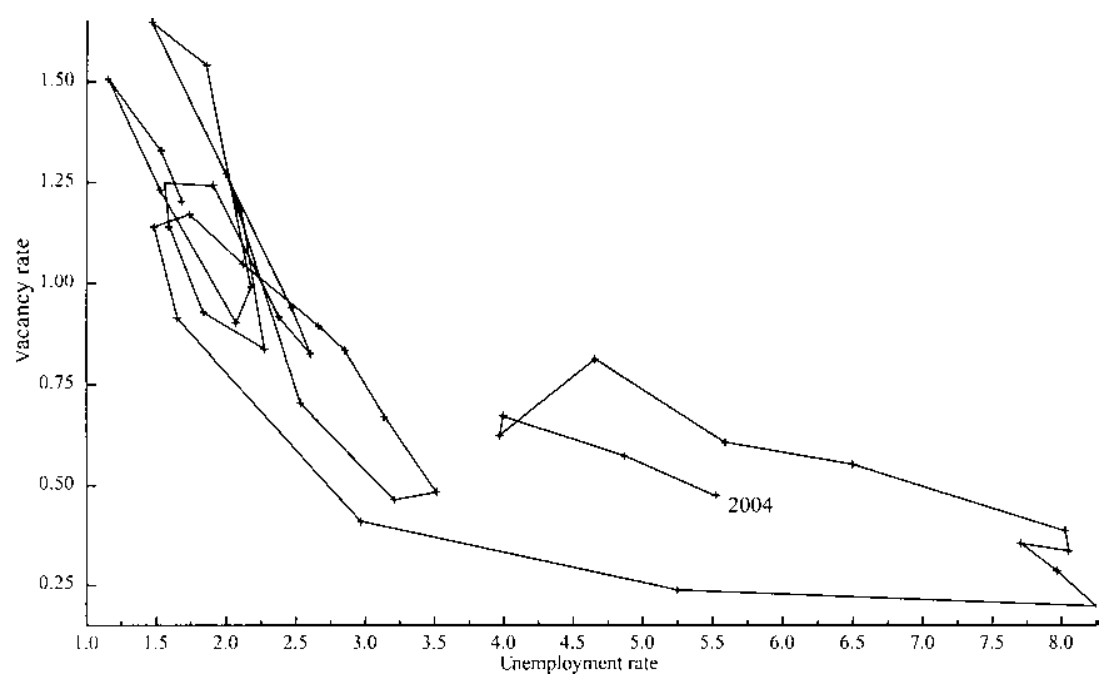

Fig. 5.7 The Swedish Beveridge curve, 1963 to 2004

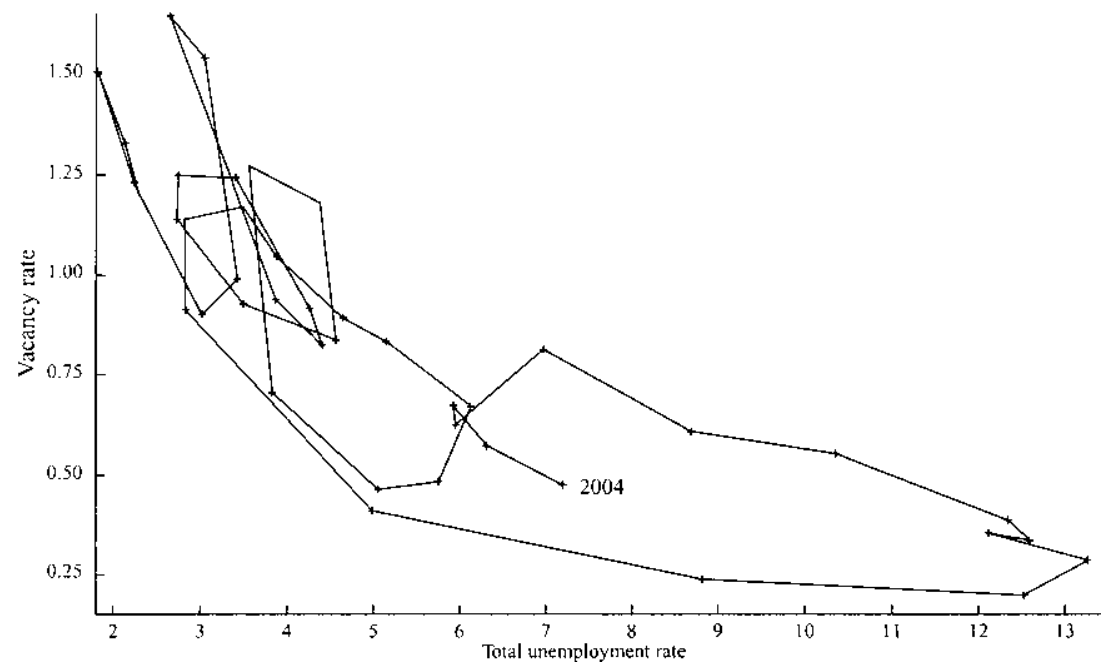

Fig. 5.8 The Swedish Beveridge curve, 1963 to 2004, in terms of total unemployment

Another way to check for changes in the functioning of the Swedish labor market is to see if the evolution of unemployment in the 1990s can be described satisfactorily by a model estimated on data ending before the crisis. To explore this idea, we have estimated an autoregressive model for unemployment.

In figure 5.9, we plot the actual unemployment rate from 1993 to 2004, 


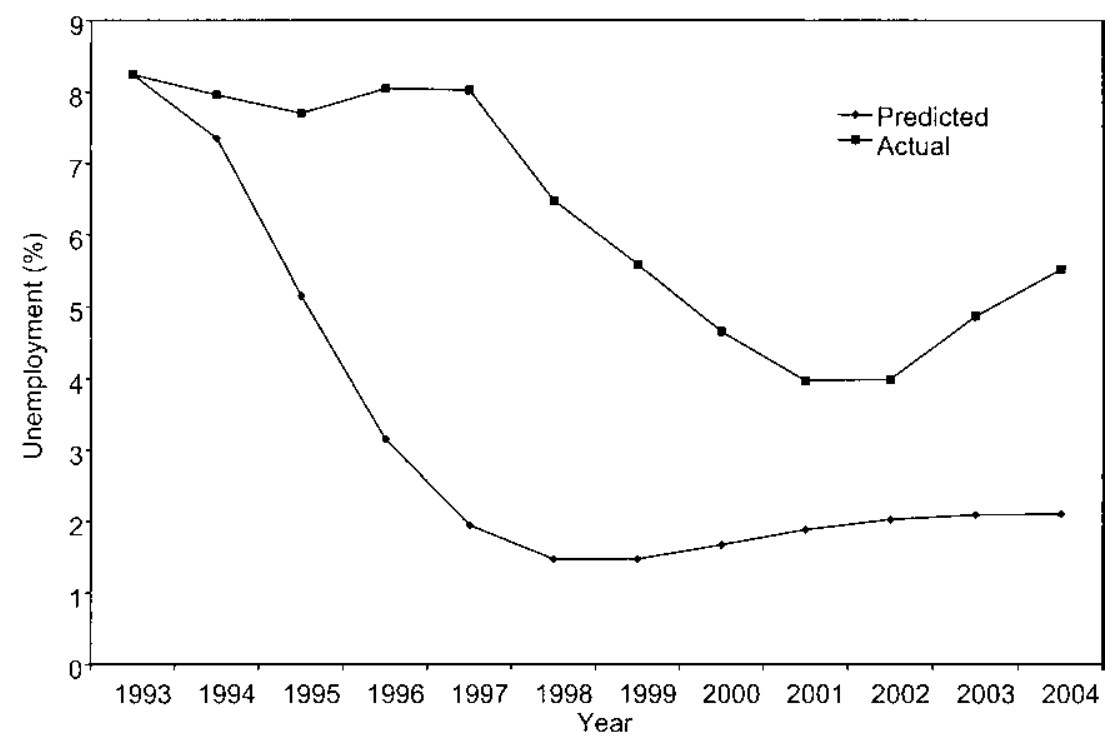

Fig. 5.9 Actual and predicted unemployment and impulse-response function for the period from 1993 to 2004

along with dynamic forecasts from this simple model estimated on unemployment data for the period from 1945 to $1990 .{ }^{1}$ The model systematically underpredicts the actual rate of unemployment, and most notably, it predicts the unemployment rate to fall four years earlier than it actually does. According to this evidence, it seems that something happened with consequences for the persistence of unemployment in the 1990s. This would seem to bear out our concern that ALMPs were unlikely to prevent persistently high unemployment from taking root and that generous safety net programs could lead to hysteresis if the stigma associated with program participation was eroded.

There is an extensive research literature on possible explanations as to why high unemployment rates may become persistent. One such factor, often discussed in connection with the Western European unemployment problem, is that the average length of unemployment spells tended to increase hand in hand with the higher unemployment rates. If unemployment has a causal negative effect on the probability that the unemployed find jobs, and if this effect tends to increase with the duration of unemployment spells, then this mechanism is one way to explain why high unemployment may become persistent. This situation could be exacerbated if high unemployment causes people to take more advantage of the panoply of safety net programs.

The increase in duration of the survey-based measure of Swedish unem-

1. This estimation period is chosen because unemployment seems to have followed a reasonably stable process over this period; see figure 5.1 . 
ployment shown in figure 5.6 is not that dramatic: duration grew from some fifteen weeks to about twenty-five weeks in the mid-1990s and then fell again. However, there is reason to believe that this measure understates the extent of the problem, because many spells of open unemployment ended in a labor market program. Hence, in figure 5.10, we use information from the registers at the National Labor Market Board to compute the average duration of both ongoing spells of open unemployment and continuous spells of open unemployment and program participation.

Using the information in figure 5.10, the development is much more ominous: the average length of spells increased more or less continuously from around 400 days in 1994 to around 700 days (one hundred weeks) in $2000 .^{2}$ At the same time, the average duration of spells of open unemployment was only about one hundred days (fifteen to sixteen weeks; see figure 5.6).

Hence, the long continuous spells of open unemployment and program participation, on average, entail significant variation. Because the average spells of open unemployment are much shorter, a large number of unemployment spells end after only a few weeks. At the same time, there must be a number of spells that are significantly longer than the average. This is shown in figure 5.11, which shows the distribution of spells of different lengths in the stocks of the registered at the Public Employment Service (PES) on December 31, 1999, and February 28, 2005.

At both dates, a vast majority had relatively short spells: between 60 and 70 percent of the spells had durations of no longer than a year. But we also see that a significant proportion (just above 14 percent, or about 62,000 persons in 1999, and just above 7 percent, or about 32,000 persons in 2005) had been registered for at least three years. Comparing the two years, we see that spells were generally shorter in 2005 , but the difference was not striking. We have also computed the average number of programs per person, conditional on participation in at least one program. This average was between 2.5 and 3 at both points in time, and around 10 percent had at least six program spells.

In our previous paper, we investigated whether the stability of the Beveridge curve (atypical for most European countries) and the low Swedish unemployment rates prior to the 1990s could be attributed to an expansion of public employment, but we did not find strong support for this hypothesis.

However, it is interesting to note that the share of public employment has developed quite differently in the 1990s than in the previous decades. This is evident from figure 5.12, which shows the evolution of the public employment share for the period from 1970 to 2004. If the increasing share contributed to lower unemployment in previous decades, ${ }^{3}$ then the sharp

2. To some extent, this increase is an artifact, reflecting the fact that the registers only date back to August 1991. However, the level in the late 1990s is probably well measured.

3 . We are a bit reluctant to push this point, however, given that we found no strong support for this hypothesis in our previous paper. 


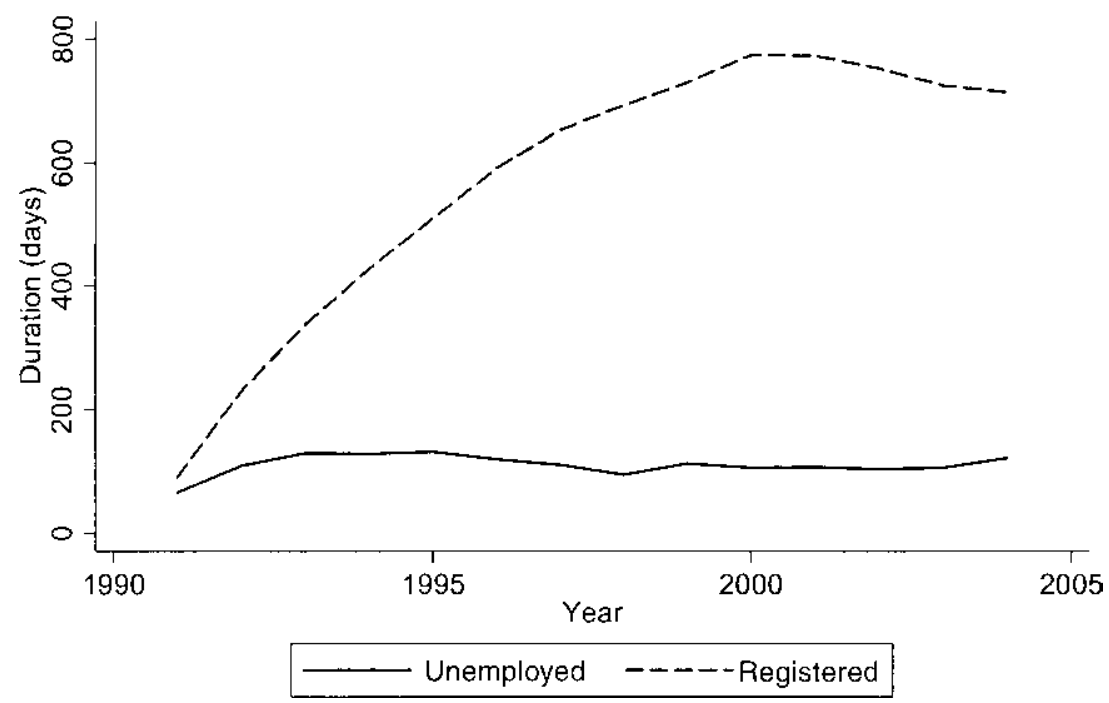

Fig. 5.10 Duration of ongoing unemployment and register spells at the Public Employment Service, averages

Source: National Labor Market Board.

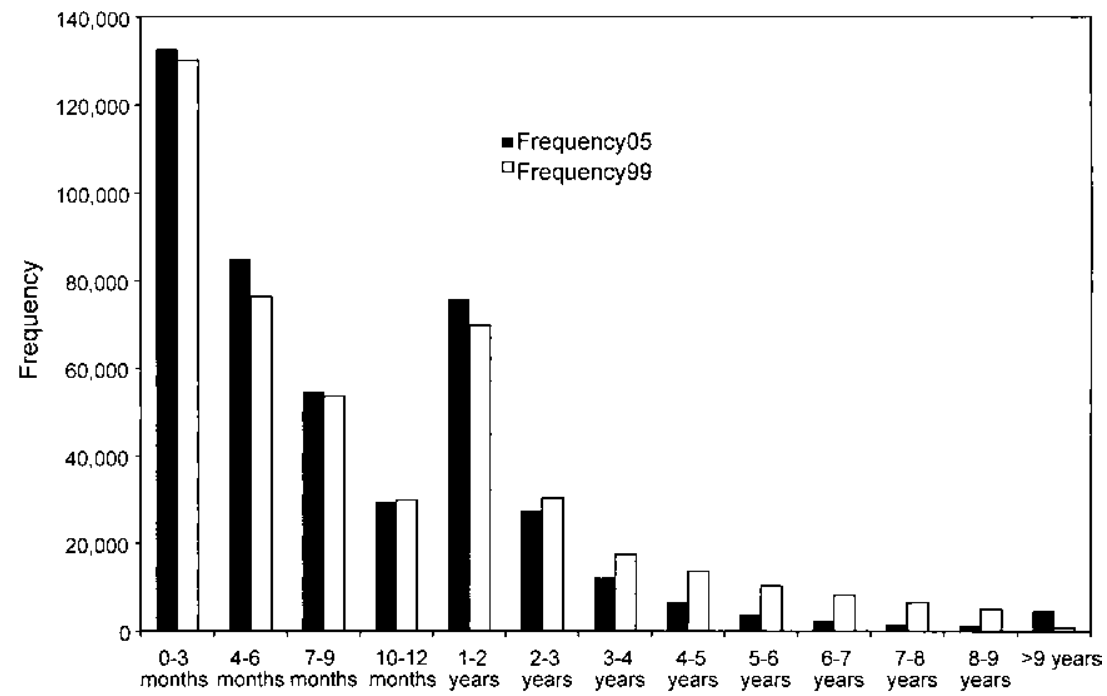

Duration

Fig. 5.11 Distribution of durations of ongoing spells in the registers of the National Labor Market Board: February 28, 2005, and December 31, 1999 


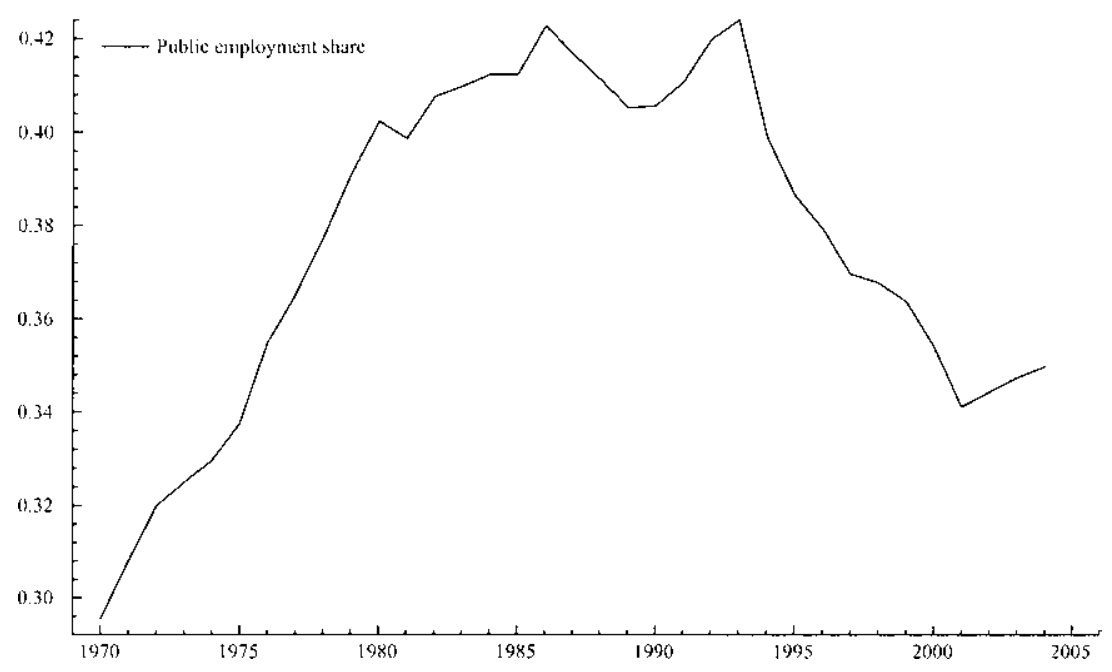

Fig. 5.12 The share of public employment, 1970 to 2004

decline in the 1990s may have contributed to the relatively high unemployment rate later.

We have estimated autoregressive models for private- and public-sector employment. The estimation samples cover the years from 1970 to 1992. Using these autoregressions to forecast employment from 1993 to 2004 gives rise to the results plotted in figure 5.13 and figure 5.14. Although these should not be given any causal interpretation, it is evident that private-sector employment evolved in a way that is fairly well described by the model estimated on data for the 1970s and 1980s, whereas the path of public-sector employment is radically different in the 1990s - the model overpredicts public-sector employment significantly in every single year from 1993 on. It is also notable that there has been no recovery in public employment since the mid-1990s. The difference to previous decades in this respect is striking.

\subsubsection{Regional Adjustments}

The evidence presented in Forslund and Krueger (1997) suggested that Swedish regional employment dynamics resembled those in other European countries, whereas the pattern of regional unemployment dynamics was more similar to that in the United States.

Fredriksson (1999) estimated regional values at risk (VARs) to analyze the dynamic adjustment to regional employment shocks. His main results were that a region-specific negative employment shock in the long run lowers employment in that region. The reduction was smaller than what is found for a typical U.S. state. In this respect, it was found that Sweden resembled the rest of Europe. Looking instead at the short-run dynamics, most of the 


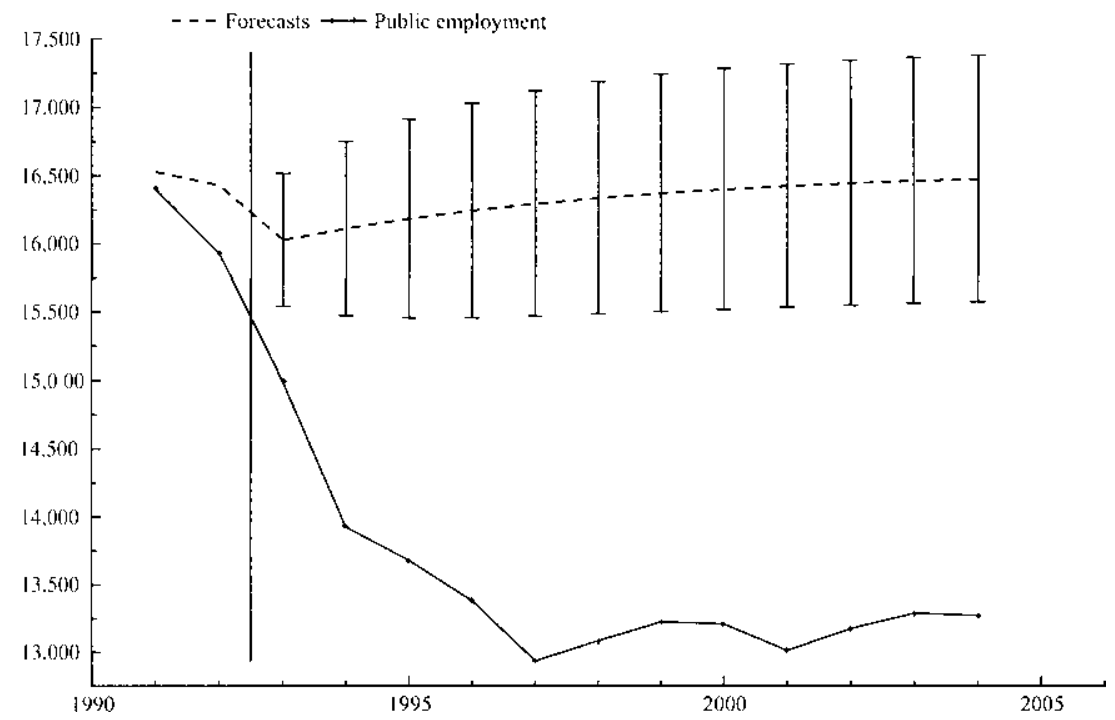

Fig. 5.13 Public-sector employment and dynamic forecast from autoregression model

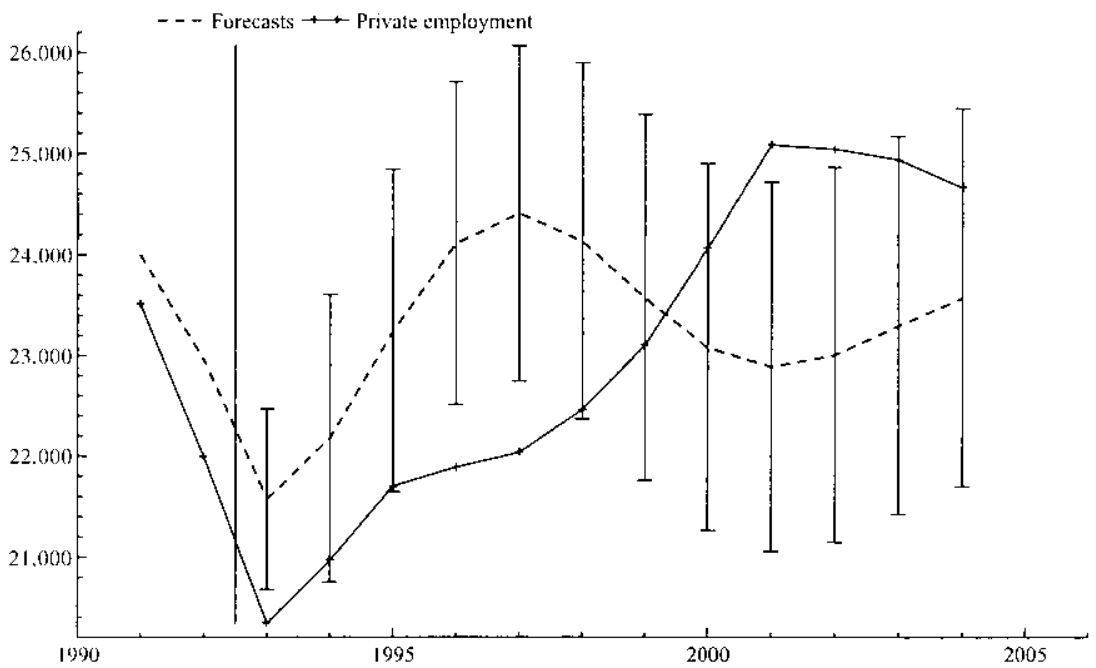

Fig. 5.14 Private-sector employment and dynamic forecast from autoregression model 
adjustment is brought about by migration and very little by unemployment, wages, or labor market programs. In this respect, Sweden was found to be rather similar to the United States. The results do not suggest that ALMPs played any major role for mobility.

A number of studies have estimated the effects of labor market policies on geographical mobility more directly. There is a small number of studies of various mobility-enhancing programs (Storrie and Nättorp 1997; Harkman 1988; Westerlund 1998). These studies suggest that the mobility-enhancing measures have had minor or no effects on mobility between counties or local labor markets. A larger number of studies have estimated the effects of placement in different programs on mobility (McCormick and Skedinger 1991; Nilsson 1995; Westerlund 1997; Edin, Heiborn, and Nilsson 1998; Westerlund 1998; Widerstedt 1998; Fredriksson and Johansson 2003; Lindgren and Westerlund 2003). Most studies suggest that programs lock in participants and hence that increasing program participation decreases mobility. An interesting insight into possible mechanisms is provided by the analysis in Fredriksson and Johansson (2003), where it is shown that the negative program effect on mobility reflects a decreased job-finding rate among participants. Given the lower job-finding rate, the propensity to move by program participants is not significantly different from the propensity to move among nonparticipants.

\subsection{Swedish ALMPs Since the Early 1990s}

\subsubsection{The Program Menu: New and Old Medicine}

The labor market programs can be subdivided into three main categories: training, subsidized employment, and practice. During the 1990s, many new programs were launched, and the following description is not exhaustive.

For a long time, labor market training was equivalent to vocational training, but over time, it also came to involve more prep courses. More recently, it also has involved computer activity centers, as well as an information technology (IT) training program organized jointly with the Confederation of Swedish Industries. Between the late 1980s and the early 2000s, participation in training programs enabled participants to renew UI benefit eligibility. This system was abolished for all labor market programs in 2000 in connection with a reform in the UI system and the introduction of the activity guarantee (see the following).

Subsidized employment has taken many forms, with the provision of relief jobs a prominent historical approach. In the 1990s, however, relief jobs were used to a small extent (and were abolished in 1998). They largely were replaced by so-called work experience schemes, where participants were supposed to be placed in jobs that would otherwise not have occurred in order to avoid crowding-out effects. In 1998, employment subsidies, which 
entail wage subsidies to employers for hiring unemployed (mainly long-term unemployed) workers, replaced recruitment subsidies, introduced in 1981. In most respects, employment subsidies are similar to the previous program, the main difference being that the new program is targeted more heavily at the long-term unemployed.

Work practice programs are supposed to involve both work and training. Normally, the participant is paid an amount corresponding to his or her level of UI compensation. A number of programs targeted toward youth belong to this category (youth teams, schooling-in slots, youth practice, municipality youth programs, youth guarantee). There were also practice programs targeted at other groups-immigrants and unemployed school graduates. Many of the practice programs were replaced by a more general work placement program in 1995.

Resource jobs were introduced in 1997. This program was a subsidy to employers for temporarily hiring unemployed workers. Participants were supposed to both work and to undergo training. The wage rate was capped at 90 percent of the participant's previous income.

Trainee replacement schemes, used between 1991 and 1997, involved subsidizing employers who paid training for an employee and who hired a replacement from the PES. Hence, this program was a mixture of training and subsidized employment.

In August 2000, a new type of program, the activity guarantee, was inaugurated (Forslund, Fröberg, and Lindqvist 2004). The activity guarantee was (and is) targeted at persons at risk of becoming long-term registers at the PES or at those with expiring UI benefit eligibility. Participation is supposed to be full-time, and the participants receive the equivalent of UI benefits. The activity guarantee is a framework within which the participant is supposed to search for a job, to participate in a regular labor market program, or to be engaged in some training program. There are only three ways to leave the guarantee: by finding a regular job lasting at least six months, by participating in regular education, or by leaving the labor force.

The inauguration of the activity guarantee was synchronized with changes in the rules in the UI system, taking place in February 2001. The main changes introduced were that first, participation in labor market programs no longer qualities for renewed UI benefit eligibility - the only way to renew eligibility is through an ordinary job; and second, if an unemployed worker has not found a job within the fourteen months of UI benefits, a case worker at the PES office decides whether the individual is to be transferred to the activity guarantee, or if the case worker assesses that the unemployed individual has a good chance of finding a job, he or she may award the individual another period (fourteen months) of UI benefits. If the unemployed has not found a job after a second period of UI benefits, he or she will be transferred to the activity guarantee or will lose all income support (possibly apart from means-tested social assistance). 
Looking at the changes in ALMPs and UI from a bird's eye view, one can distinguish an increased focus on job search: a main feature of the activity guarantee is supposed to be full-time job search. One can also detect an increased focus on the long-term unemployed: several forms of the employment subsidies that have been in use since 1998 have been targeted explicitly at the long-term unemployed.

\subsubsection{A Quantitative Description}

In figure 5.15, we show the evolution of the different types of labor market programs since the early 1960s. Both training programs and subsidized employment trended up until the mid-1990s. Training programs had more participants than subsidized employment during most of this period. Practice programs were of a rather limited importance throughout the 1980s. A number of observations can be made concerning the 1990s. First, the measure of first resort to meet the rise in unemployment was training programs, which were expanded rapidly during 1991 . This is a contrast to previous decades, when relief jobs were used as the primary countercyclical measure. Second, after some time, participation in subsidized employment programs reached very high levels at the same time that practice programs expanded and training programs decreased in volume. When the labor market improved in the late 1990s, participation in all kinds of programs declined, and in the early 2000s, the three types of programs were of approximately equal size.

\subsubsection{Interactions between UI and ALMPs}

A generous ${ }^{4}$ unemployment insurance creates incentives that are likely to cause long unemployment spells. A number of reforms in the Swedish UI system have facilitated an analysis of the effects of changes in the level of compensation on the flow from (insured) unemployment to employment.

Carling, Holmlund, and Vejsiu (2001) studied a change in the replacement rate from 80 percent to 75 percent that was introduced on January 1, 1996. This reform only affected a subsample of the unemployed. The authors estimated the effect of the reform by comparing job-finding rates before and after the reform of those affected and unaffected. The estimates suggested that the cut in the replacement rate resulted in an increase in the job-finding rate by about 10 percent.

Bennmarker, Carling, and Holmlund (2007) investigated the effects of several changes in the unemployment insurance system introduced in 2001 and 2002. In 2001, a two-tiered benefit system was introduced. The new system entails a higher compensation during the first twenty weeks of an unemployment spell. In 2002, benefits were raised both for spells exceeding

4. This is in terms of compensation levels and duration, as well as in terms of the level of control the system has in ensuring that the unemployed who is receiving benefits actually is looking actively for a job. We described the basics of the Swedish system in Forslund and Krueger (1997). 


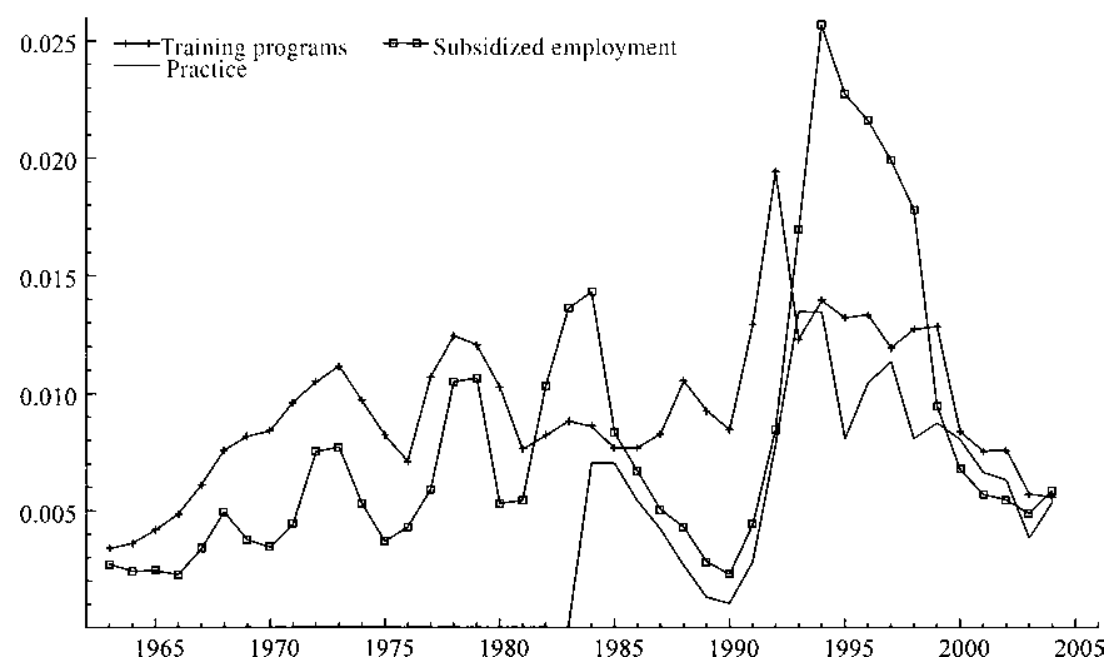

Fig. 5.15 Different ALMPs, 1963 to 2004 (shares of labor force)

twenty weeks and for the first twenty weeks of spells. The changes applied, as was the case in the 1996 reform, only to subsamples of the unemployed. Once again, this was used to identify effects on job-finding rates. Somewhat surprisingly, there is a striking difference between the results for males and females. The female job-finding rate was increased, whereas the male job-finding rate (in accordance with theoretical expectations) was reduced. There was no significant effect on the aggregate job-finding rate. The authors speculated that the difference between males and females was due to a reform in child care that took place simultaneously. The expected effect of this reform was to increase female labor supply.

A peculiarity of Swedish labor market policies in the 1990s was the opportunity to renew UI benefit eligibility through participation in labor market programs. ${ }^{5}$ Given the generous Swedish UI system for unemployed members, this feature is likely to have affected both the efficacy of program participation and the work disincentives associated with the combined system of UI and labor market programs by lengthening benefit receipt. Indeed, there is accumulating evidence suggesting that the system led to cycling between unemployment and program participation and that this adversely affected the results of program participation. ${ }^{6}$

First, Ackum Agell, Björklund, and Harkman (1995) showed that long spells in the registers of the National Labor Market Board (including both

5. Provided that the program lasted long enough, participation in any program counted as employment and hence gave renewed benefit eligibility. Before 1986, only participation in joblike programs, such as relief jobs, qualified.

6. In Forslund and Krueger (1997), we presented some evidence consistent with these results, but we concluded that there was no direct conclusive evidence. 
UI and program periods) were common in the early 1990s. Carling et al. (1996) showed that UI-compensated unemployment spells close to benefit exhaustion were significantly more likely to lead to program participation than were uncompensated unemployment spells. Sianesi (2001) found that program participation increased the probability of future benefitcompensated unemployment, as well as subsequent program participation. These effects were both nontrivial in size and long lasting. Finally, Hägglund (2000) found that both employment durations and the length of program spells were affected by changes in UI eligibility criteria.

Second, Sianesi (2001) found that the treatment effect (in terms of a number of different outcomes) of programs was among the worst for those individuals who were joining the programs around the time of UI benefit exhaustion, although it is hard to rule out that unobserved personal factors that lead to program participation late in the spell of unemployment, rather than the opportunity to participate itself, caused this result, absent a randomized experiment. In either interpretation, this result is consistent with the finding in Regnér (1997) and Harkman (2002) that unemployed job seekers often entered programs just to renew UI benefit eligibility.

Therefore, the evidence suggests that the system promoted cycling between periods of (UI-compensated) unemployment and program participation and hence longer periods of nonemployment. In countries that prohibit long-term cycling between open unemployment and labor market programs, it typically is found that shorter durations of compensated unemployment spells are associated with shorter unemployment spells. ${ }^{7}$

The possibility to renew benefit eligibility was removed in August 2000, when the activity guarantee ${ }^{8}$ was introduced. Apart from other possible effects of the activity guarantee, this reform should be expected to improve the results of the active labor market programs.

\subsubsection{Research Results on Swedish ALMPs: A Survey}

Evaluations of ALMPs may be divided into micro- and macrostudies. The microstudies establish program effects for participants, whereas macrostudies consider general equilibrium effects of the programs (i.e., also consequences for nonparticipants). Typical microstudies estimate effects of program participation on subsequent income or employment; the macrostudies cover more diverse topics such as displacement effects, effects on matching efficiency, or effects on unemployment or wages.

Microevaluations depend on good data. In the United States, the modest amount of resources allocated to ALMPs has been accompanied by a fairly large amount of experimental evaluations. In Sweden, there still has been

7. Moffitt (1985), Meyer (1990), and Katz and Meyer (1990) for the United States; Ham and Rea (1987) for Canada; Dormont, Fougere, and Prieto (2001) for France; and Ahn and Garcia-Perez (2000) and Jenkins and Garcia-Serrano (2000) for Spain.

8. See section 5.3.1 for a description of the activity guarantee. 
only one small experiment carried out for evaluation purposes (in 1974). Instead, Swedish evaluations have to rely on register data. This effort has been aided by the fact that the supply of register data has grown remarkably since the early 1990s, when the National Labor Market Board initiated an event database with information on all job applicants registering as job seekers at the Public Employment Service. Subsequently, these data have been matched with other register data from Statistics Sweden, giving rise to extremely rich observational databases for evaluation purposes. In the wake of the better data supply and the large program volumes in the 1990s, the number of high-quality evaluations of Swedish ALMPs has grown significantly since our previous paper. The number of macroevaluations, in contrast, has grown only marginally. We continue to think that it is unfortunate that Sweden still has not initiated randomized controlled evaluations of its labor market programs. Absent controlled studies, it is impossible to know if the programs or some other factors that are correlated with program participation are responsible for the measured success or failure of the programs in observational studies.

We begin by reviewing microevidence for different programs. Then, we take a closer look at some selected macrotopics.

\section{Training Programs}

In Forslund and Krueger (1997), we concluded that based on the available evidence, we could neither rule out that the returns to labor market training were 0 , nor that they exceeded 3 percent, which were roughly the returns needed to make the investment worthwhile. Since then, a number of new evaluations of training programs have been published, and some patterns have emerged that may be used to refine the previous conclusions. ${ }^{9}$

The main impression conveyed by the studies is that there was a difference in the effects of training when comparing the 1980s and the 1990s, where the estimated effects generally looked more favorable in the 1980s. Indeed, most studies pertaining to (especially) the early 1980s point to nontrivial positive effects, whereas studies pertaining to the 1990s indicate insignificant results at best. ${ }^{10}$

There is no hard evidence available to account for these differences, but there are many possible explanations. First, for training to be effective, there should be easily identified bottlenecks for which to train. This is less likely in a deep recession (like in the 1990s) than in a more normal labor market (like in the 1980s). Second, the number of participants was much larger in the 1990 s than in the 1980s, and the growth rate in the number of participants in the early 1990s was remarkable. (The number of participants doubled during the second half of 1991.) Such high volumes and growth rates may

9. Most studies are reviewed in some detail in Calmfors, Forslund, and Hemström (2004).

10. The studies either estimate effects on subsequent income or on the hazard to work. 
have had detrimental effects on quality. Third, in the early 1990s, as opposed to in the early 1980s, participation in a (sufficiently long) training program could be used to renew UI benefit eligibility. To the extent that a fraction of the participants were motivated by a desire to renew benefit eligibility rather than to acquire useful skills, this is another possible explanation of the difference in estimated effects.

In 1997, a new program was introduced - the so-called adult education initiative (AEI). The program was targeted at unemployed workers with low levels of education, who were given the opportunity to take part in regular adult education while receiving the equivalent of unemployment benefits. It was a major program: between 1997 and 2000, more than 10 percent of the labor force participated. A number of studies (Albrecht, van den Berg, and Vroman 2004; Axelsson and Westerlund 2004, 2005; Ekström 2003; Stenberg 2003, 2005; Stenberg and Westerlund 2004) have estimated various types of effects of the program. The evidence on effects for the treated is mixed and depends on both the outcome measures and the methodology applied. Albrecht, van den Berg, and Vroman (2004) calibrated a general equilibrium search model and found positive effects for the treated but negative effects for the nontreated low-skilled workers.

\section{Time Use of the Unemployed}

To further examine how ALMPs affect the experience of unemployment in Sweden and the United States, we used Swedish time-use data for 2000 to 2001 and the American Time-Use Survey (ATUS) for 2003 to 2005 to examine how the unemployed spend their time in the two countries. Ideally, we would prefer to examine years that are at more comparable points of the business cycle, but these are the only data we have available at this time. There is also a question as to how comparable the data are. The Swedish data are based on tabulations from the Harmonized European Time-Use Surveys, which only summarize results in categories. Job-search activities for Sweden are represented in the category "activities related to employment," which includes some activities in addition to job search.

The ATUS has an activity category for job search and related activities. Unemployed American workers spend 0.55 hours per day on weekdays and 0.4 hours per day on weekends engaged in searching for a job or in related activities. The corresponding figures for Swedish workers are much lower: just six minutes per day on weekdays and one minute on weekends. Thus, the Swedish unemployed devote very little time to job search compared with the Americans. In addition, a smaller proportion of unemployed Swedes engage in job search on any given day than do Americans. Interestingly, both the American and Swedish unemployed workers report spending about onethird of an hour per day involved in education of some form. Surprisingly, we do not see much of a difference in the amount of time spent on training. While these results should be taken with a grain of salt, given the difficulties 
inherent in international comparisons of time use - and other factors that matter for job search intensity, such as the extent of variability in wages across comparable jobs - one plausible implication of this pattern is that Swedish ALMPs and unemployment compensation may have discouraged search effort as compared with American job seekers.

The outward shift of the Beveridge curve in Sweden suggests that the unemployed have become less likely to fill available vacancies. This shift is consistent with reduced job search activity by the unemployed in Sweden, although we do not have time series data on job search time. In any event, this comparison indicates that time-use data can provide useful insights into the behavior of the unemployed.

\section{Other Microevaluation Results}

A number of recent evaluation studies either have compared the effects of participation in different programs or have compared program participation to continued job search of the openly unemployed. ${ }^{11}$

A simple generalization of the results boils down to two conclusions. First, the more a program resembles an ordinary job, the more efficient it is in bringing the participant to work. This suggests that the most effective programs involve subsidizing employers to hire unemployed workers. It also implies that many of the low-budget programs used during the 1990s have proved to be the least effective in bringing unemployed persons back to work. Second, only employment subsidies (and perhaps subsidized self-employment for unemployed workers) have proved to be more effective than job search assistance. Hence, most programs, including training programs, are dominated by job search assistance, according to the available evidence.

The second result at first glance may seem counterintuitive. However, to the extent that it does, this may derive from the fact that time spent on job search may be at least as well spent as time in a program, where survey studies show that search activity goes down significantly. Against this background, the recently increased policy focus on job search seems warranted.

\section{Direct Displacement Effects}

Direct displacement takes place if employers substitute program participants for ordinary employment. In Forslund and Krueger (1997), we estimated displacement effects of relief jobs and found displacement to be high in building and construction but not significantly different from zero in health and welfare. Since then, much new evidence has accumulated. This evidence is surveyed in Calmfors, Forslund, and Hemström (2004), on which we base the following brief summary of results.

In a fairly large number of surveys, employers, program participants, and employment officers have been asked whether they believe that the tasks

11. See Calmfors, Forslund, and Hemström (2004) for a survey. 
performed by program participants would have been performed also in the absence of the program. The results in the survey studies, almost without exception, suggest that all programs are associated with substantial displacement effects, but rarely are they above 50 percent. Another main result in these studies is that displacement effects are larger when the program more closely resembles an ordinary job. These findings must be taken with a grain of salt, however, as the public's opinion of the presence or absence of displacement opportunities is not proof that displacement actually takes place.

There are also several econometric studies of displacement, however. In most cases, these studies do not look at displacement effects for single programs. The results indicate larger displacement effects than those found in the survey studies; typically, displacement effects well above 50 percent are found in the econometric studies, whereas the estimated effects in the survey studies only in a few cases exceed 50 percent.

\section{Why Do Employment Subsidies Work?}

The purpose of employment subsidies is to facilitate the transition to regular jobs for the long-term unemployed. The job-finding rate among the long-term unemployed is significantly lower than among persons with shorter unemployment spells. This may have several explanations. One possibility is that employers perceive the long-term unemployed to be less productive than other persons with the same observed characteristics. So, the employment subsidy can be considered a subsidy to employers for the risk they are taking. If the long-term unemployed person in fact has lower productivity, this in turn may be due to either permanently lower productivity among the long-term unemployed (selection) or the fact that unemployment in itself has a negative effect on a person's ability to perform work tasks. If the latter is the case, the employment subsidy - that is, a temporary wage subsidy - is a reasonable policy measure; during the subsidized period, the employed can regain the working capacity lost during the unemployment spell. If, on the other hand, the productivity is permanently lower, a temporary wage subsidy is unlikely to solve the problem permanently.

We do not know with certainty whether employment subsidies primarily compensate employers for the risk taken when employing a long-term unemployed worker or for the cost of on-the-job skills upgrading. Also, some employees undoubtedly would have been hired absent the subsidy, just as some people who use coupons to buy milk would have bought milk anyway. However, it is clear from the estimates in Forslund, Johansson, and Lindqvist (2004) that a considerable part of the positive effect of employment subsidies derives from a large flow to work at the point in time when the subsidy expires. This indicates that a substantial fraction of the positive estimated treatment effect arises because subsidized employment turns into regular jobs. This pattern would not be expected if the subsidies to a large 
extent were given to employers who hire unemployed persons with permanently low productivity. To the extent that a nontrivial share of the longterm unemployed has permanently low productivity, the problem cannot be solved without permanent adjustments of wage costs for low-productivity workers. Such adjustments can come about in a number of ways, such as wage adjustments or various permanent subsidies through the tax system.

\section{Other Macroevaluation Results}

ALMPs may affect the wage-setting process. To the extent that ALMPs are perceived as a better alternative than open unemployment, large-scale ALMPs may weaken the incentives for wage restraint created by open unemployment. If, on the other hand, ALMPs contribute to job seekers that are more competitive, this creates incentives for wage restraint; if a union pushes for high wages, which then leads to members losing their jobs, the laid-off union members will face a tougher competition for the existing jobs. Hence, a priori, the sign of the net effect on wages is ambiguous. ${ }^{12} \mathrm{~A}$ fairly large number of empirical studies have estimated the effect on wages of ALMPs. ${ }^{13}$ Most studies have found that ALMPs increase the pressure for higher wages or have no effect at all. The uncertainty about the results, however, is considerable.

A few studies have estimated Swedish Beveridge curves (Jackman, Pissarides, and Savouri 1990; Calmfors 1993) or matching functions (Edin and Holmlund 1991; Hallgren 1996; Forslund and Johansson 2007) to determine the effects of ALMPs on matching efficiency, without finding evidence suggesting that ALMPs have actually improved matching.

One important objective of ALMPs in the 1990s was to promote labor force participation: even if programs did not have immediate effects on the transition from unemployment to work, it was claimed that they could prevent marginalization, and eventually, early retirement. There is a small number of studies dealing with the effects of ALMPs on labor force participation (Wadensjö 1993; Johansson and Markowski 1995; Johansson 2001; Dahlberg and Forslund 2005). All of them find significant positive effects. However, one should be careful when interpreting these results. If program participation, at least to some extent, was used to renew UI benefit eligibility, it is not clear to what extent the increased labor force participation reflected an increase in effective labor supply.

\section{International Cross-Country Evidence on ALMPs}

In Forslund and Krueger (1997), we claimed that much of the favorable impression of ALMPs was due to cross-country studies. In that paper, we

12. A formal analysis of this is presented in Calmfors and Lang (1995) and Forslund and Kolm (2004).

13. These studies are surveyed in Calmfors, Forslund, and Hemström (2004). 
showed to some extent that these results were fragile. Calmfors, Forslund, and Hemström (2004) have surveyed this growing literature. They find that it seems to be a fairly robust result that ALMPs have contributed to lower rates of open unemployment. However, if this result should reflect that ALMPs improve the working of labor markets, one would expect that ambitious ALMPs also would contribute to lower rates of total unemployment (the sum of open unemployment and program participation). This, however, is less clear: some studies find that expanding ALMPs are associated with lower rates of total unemployment, while others find the opposite, and some studies find no significant effects at all. The implication of these two results is that ALMPs contribute to lower unemployment rates, whereas the effect on employment is unclear. Hence, the picture conveyed by the cross-country studies is rather similar to what we see in the studies of Swedish ALMPs. There are also results in the cross-country studies that are consistent with a positive effect of ALMPs on labor force participation - just as was the case for Sweden.

\subsection{Recent Changes in Swedish ALMPs}

The new right/center Swedish government replaced the Social Democrats after the 2006 general elections and rapidly introduced a number of changes in labor market policies. As of this writing, the new policies have been in place for less than a year, so there are no evaluations available. However, we can draw on evidence from similar programs and theoretical considerations to discuss expected effects.

The most fundamental changes have been introduced in the unemployment insurance program. First, replacement rates now are lowered from 80 percent to 70 percent after the first 200 days of unemployment. Second, the cap on the daily benefit, which was higher during the first one hundred days, is now constant over the entire unemployment spell. Third, the possibility of receiving more than one period (fourteen months) of UI benefits has been removed. Relatedly, compensation during time spent in labor market programs is no longer paid by the UI program. Previously, the UI clock stopped ticking during spells of program participation. This is no longer the case, meaning that periods paid either by UI or as compensation while in programs now have a maximum length of fourteen months, without exceptions. Previous theoretical and empirical research would indicate strongly that all of these changes should contribute to more rapid transitions from unemployment to work.

A fourth change involves membership fees for UI insurance fund members, which previously were independent of the level of unemployment among the members. The new government has introduced some elements of experience rating into the system by making membership fees dependent on the unemployment rate of each fund. However, the degree of 
experience rating is weak, so the expected effects should be small. ${ }^{14}$ Government subsidization has also decreased, resulting in generally higher membership fees. This feature of the reforms seems to have given rise to a rather rapid decrease in UI fund membership.

Another reform that is closely related to the UI reforms is that the previous activity guarantee has been replaced by a job and development guarantee. This reform entails several changes vis-à-vis the former activity guarantee. First, the replacement rate in the new guarantee has been reduced to 65 percent; in the activity guarantee, it was the same as the (constant) UI replacement rate. Second, when eligibility for UI benefits expires after fourteen months of unemployment, entry into the job and development guarantee is mandatory. In comparison to the old system, this means that entry into the new program, on average, will take place earlier in an unemployment spell. Additional, mostly minor changes also were introduced. The lower replacement rate in the job and development guarantee is likely to speed up the transition to work compared with the old activity guarantee; the effects of the other changes are harder to predict.

The former employment subsidy programs have been replaced by the new-start jobs program. This program gives employers a tax subsidy - the employer does not have to pay any of the 33.42 percent payroll tax - for hiring an eligible worker. Workers become eligible by having a continuous period (at least twelve months long) of unemployment, sickness absence, or social assistance receipt, combined with nonemployment. The subsidy is in effect for a period equaling the duration of time in which the employee was not employed prior to starting the subsidized job. ${ }^{15}$ The main innovation in this reform is that workers can acquire eligibility not only through a spell of unemployment but also through other spells outside the labor force. So, instead of targeting just the long-term unemployed, the new-start jobs program targets those who are more generally long-term nonemployed. It is hard to assess the importance of this reform, as well as of other differences between the old and the new programs, although Katz (1996) provides some evidence that targeted-jobs tax subsidies have increased employment in the United States in the past.

A few changes, specifically in youth programs, have also been implemented. First, payroll taxes are halved for all young workers (below age twenty-five). As a vast majority of youth qualifying for this benefit probably would have been employed anyway, this reform is likely to result in nontrivial tax transfers, causing deadweight costs due to lost tax revenue that will have be made up elsewhere. Second, the responsibility for providing the programs has been removed from the municipalities; youth programs,

14. In the Swedish system, the expected effects of experience rating primarily would be effects on wage setting; see, for example, Holmlund and Lundborg (1988). See Card and Levine (1994) for evidence of the effects of experience rating on unemployment in the United States.

15. There are exceptions for young people, old people, and immigrants. 
like other programs, are now administered by the National Labor Market Board. This new program is called the job guarantee for youth. The available evidence suggests that transferring the responsibility away from the municipalities may have beneficial effects (Forslund and Nordström Skans, 2006). Third, according to the new policy guidelines, job search activities will be the main component of the first phase of the program. Evidence from the U.K. New Deal for Young People gives some support for this focus (see Blundell et al. 2000).

Some reforms outside of labor market programs are also likely to affect the labor market. For example, the new government has instituted tax reforms that are clearly designed to affect labor supply. We leave these issues for another chapter, as our focus is primarily on labor market programs.

\subsection{Concluding Discussion}

There are indications that the modus operandi of the Swedish labor market changed during the 1990s. Most importantly, we have documented that unemployment followed a different, less favorable pattern after the crisis of the 1990s than during the previous four decades. This could reflect the fact that some of those who lost their jobs in the early 1990s remained jobless during very long periods and became less employable in that process. This in turn could reflect the possibilities to renew UI benefit eligibility through participation in labor market programs. Labor market policies, in this respect, simply enabled people to remain jobless for a longer period of time. The possibility to renew UI benefit eligibility also seems to have had a negative influence on the treatment effect of labor market programs.

Available evaluations of labor market programs in the 1990s indicate that the only program that led to a job more rapidly than job search in open unemployment was employment subsidies (before 1998 recruitment subsidies). At the same time, such programs probably are associated with displacement effects, so the net effect on open unemployment may be small.

Altogether, these results suggest that the labor market policies of the 1990s were not well adapted to combat the unemployment that arose in the first years of the 1990s.

Was there an alternative? From an American perspective, it perhaps would seem natural to lower the levels of the social safety nets and in this way to make the unemployed persons seek, find, and accept new job offers more rapidly. Safety nets at the U.S. level, however, are not a realistic alternative in Sweden. For example, according to the OECD (2004), the level of compensation for an unemployed person was considerably lower in the United States than in Sweden (30 percent of previous income in the United States, compared to 77 percent in Sweden) counted over a long period (five years) of unemployment. An explanation of the big difference is that UI benefits normally are limited to six months in the United States. Thereafter, only 
time-limited means-tested support and disability insurance are available in the United States.

The finding that program participation generally was outperformed by job search, however, points to another alternative. If the social safety nets are kept at a high level, job search and job acceptance incentives must be provided in other ways. One such way is job search assistance and counseling. In the international evaluation literature, there is evidence that job search assistance is one of the few examples of successful measures. ${ }^{16}$ While it is unclear why job search assistance is such a cost-effective strategy, one possibility is that such programs provide the unemployed with a more reasonable expectation for the type of jobs that they might be able to obtain (which has the economic effect of lowering reservation wages). The effectiveness of job search assistance partly may relate to our finding from time-use data that unemployed Swedes devote comparatively little time to job search.

In many circumstances, a distinction is made between active labor market policies (labor market programs) and passive labor market policies (UI benefits). This distinction seems to be based on a notion that UI benefits are paid as a compensation for not working. This is a misleading distinction for Sweden. In all existing UI benefit systems, there is a set of rules designed to ascertain that the unemployed person is available for work and is actively searching for a job in different ways. In Sweden, the Public Employment Service is the spider in this web. The PES is supposed to provide both counseling and monitoring to make sure that unemployed persons with UI benefits are available for work, according to the rules of UI. The activities of the PES in this perspective should be viewed as a (potentially) efficient labor market program. An alternative to the labor market policies pursued in the 1990s, therefore, would have been to allocate more resources to job counseling and monitoring and less to other programs.

From a perspective based on the experiences from the 1990s, the reforms in labor market policies in the early 2000 s seem to be steps in the right direction. The activity guarantee involves an increased focus on measures to stimulate job search, and the new rules in UI have removed the problem of the 1990s of cycling between programs and open unemployment. The demise of relief jobs and the increased emphasis on employment subsidies is another development that is likely to lead to more efficient job creation. Of course, this does not mean that Swedes live in the best of all possible worlds. Unemployment is still high, and many problems of (potential) low-wage earners remain to be solved. In addition, the 1990s have left a legacy of long-term unemployed persons who have had only sporadic contacts with the regular labor market. As our discussion of wage subsidies suggests, traditional labor market policies probably can not solve all these problems. Yet, Sweden's commitment to improving labor market conditions and its policymakers' 
willingness to experiment with different and innovative approaches when past approaches proved less effective than desired are positive signs.

\section{References}

Ackum Agell, S., A. Björklund, and A. Harkman. 1995. Unemployment insurance, labour market programmes and repeated unemployment in Sweden. Swedish Economic Policy Review 2 (2): 101-28.

Ahn, N., and J. I. Garcia-Perez. 2000. Unemployment duration and workers' wage aspirations in Spain. Working Paper no. 426. Universitat Pompeu Fabra, Department of Economics and Business, March.

Albrecht, J., G. J. van den Berg, and S. Vroman. 2004. The knowledge lift: The Swedish adult education program that aimed to eliminate low worker skill levels. IFAU Working Paper no. 2004:17. Uppsala, Sweden: Institute for Labor Market Policy Evaluation.

Axelsson, R., and O. Westerlund. 2004. Kunskapslyftets privatekonomiska effekter: Nybörjare höstterminen 1997. Umeå Economic Studies Working Paper no. 630. Umeå University, Department of Economics.

- 2005. Kunskapslyftets effekter på årsarbetsinkomster. Umeå Economic Studies Working Paper no. 647. Umeå University, Department of Economics.

Bennmarker, H., K. Carling, and B. Holmlund. 2007. Do benefit hikes damage job finding? Evidence from Swedish unemployment insurance reforms. Labour: Review of Labour Economics and Industrial Relations 21 (1): 85-120.

Blundell, R., A. Duncan, J. McCrae, and C. Meghir. 2000. The labour market impact of the working families tax credit. Fiscal Studies 21 (1): 75-103.

Calmfors, L. 1993. Lessons from the macroeconomic experience of Sweden. European Journal of Political Economy 9 (1): 25-72.

Calmfors, L., A. Forslund, and M. Hemström. 2004. The effects of active labormarket policies in Sweden: What is the evidence? In Labor market institutions and public regulation, ed. J. Agell, M. Keen, and A. Weichenrieder, 1-63. Cambridge, MA: MIT Press.

Calmfors, L., and H. Lang. 1995. Macroeconomic effects of active labour market programmes in a union wage-setting model. Economic Journal 105 (430): 601-19.

Card, D., and P. B. Levine. 1994. Unemployment insurance taxes and the cyclical and seasonal properties of unemployment. Journal of Public Economics 53 (1): $1-29$.

Carling, K., P.-A. Edin, A. Harkman, and B. Holmlund. 1996. Unemployment duration, unemployment benefits, and labor market programs in Sweden. Journal of Public Economics 59 (3): 313-34.

Carling, K., B. Holmlund, and A. Vejsiu. 2001. Do benefit cuts boost job-findings? Swedish evidence from the 1990s. Economic Journal 111 (474): 766-90.

Dahlberg, M., and A. Forslund. 2005. Direct displacement effects of labour market programmes. Scandinavian Journal of Economics 107 (3): 475-94.

Dormont, B., D. Fougère, and A. Prieto. 2001. L'effet de l'allocation unique dégressive sur la reprise déemploi. Théorie Economique, Modélisation et Applications (THEMA) Working Paper no. 2001-05. Paris: Université de Cergy-Pontoise.

Edin, P.-A., M. Heiborn, and C. Nilsson. 1998. Inter-regional migration in Sweden. In Economic studies, vol. 40, Essays on demographic factors and housing markets, ed. M. Heiborn. Uppsala University, Department of Economics.

Edin, P.-A., and B. Holmlund. 1991. Unemployment, vacancies and labour market 
programmes: Swedish evidence. In Mismatch and labour mobility, ed. F. P. Schioppa, 405-49. Cambridge: Cambridge University Press.

Ekström, E. 2003. Essays on inequality and education. PhD thesis, Uppsala University.

Forslund, A., D. Fröberg, and L. Lindqvist. 2004. The Swedish activity guarantee. OECD Social, Employment and Migration Working Paper no. 16. Paris: Organization for Economic Cooperation and Development, January.

Forslund, A., and K. Johansson. 2007. Random and stock-flow models of labour market matching: Swedish evidence. IFAU Working Paper no. 2007:11. Uppsala, Sweden: Institute for Labor Market Policy Evaluation.

Forslund, A., P. Johansson, and L. Lindqvist. 2004. Employment subsidies: A fast lane from unemployment to work? IFAU Working Paper no. 2004:18. Uppsala, Sweden: Institute for Labor Market Policy Evaluation.

Forslund, A., and A.-S. Kolm. 2004. Active labor market policies and real-wage determination: Swedish evidence. In Research in labor economics, vol. 23, Accounting for worker well-being, ed. S. Polachek, 381-441. Amsterdam: Elsevier.

Forslund, A., and A. Krueger. 1997. An evaluation of the active Swedish labor market policy: New and received wisdom. In The welfare state in transition: Reforming the Swedish model, ed. R. Freeman, R. Topel, and B. Swedenborg, 267-99. Chicago: University of Chicago Press.

Forslund, A., and O. Nordström Skans. 2006. Swedish youth labour market policies revisited. Vierteljahrshefte zur Wirtshaftsforschung 75 (3): 168-85.

Fredriksson, P. 1999. The dynamics of regional labor markets and active labor market policy: Swedish evidence. Oxford Economic Papers 51 (4): 623-48.

Fredriksson, P., and P. Johansson. 2003. Employment, mobility, and active labor market programs. IFAU Working Paper no. 2003:3. Uppsala, Sweden: Institute for Labor Market Policy Evaluation.

Hägglund, P. 2000. Effects of changes in the unemployment insurance eligibility requirements on job duration: Swedish evidence. IFAU Working Paper no. 2000:4. Uppsala, Sweden: Institute for Labor Market Policy Evaluation.

Hallgren, A. 1996. Job matching and labour market programmes in Sweden. Licentiate diss., Uppsala University.

Ham, J., and S. Rea. 1987. Unemployment insurance and male unemployment duration in Canada. Journal of Labor Economics 5 (3): 325-53.

Harkman, A. 1988. Arbetsmarknadspolitikens effekter på geografisk rörlighet: En tvärsnittsstudie av arbetslösa 20-29-åringar. AMS Rapport från utredningsenheten 1988:19. Stockholm: Swedish National Labor Market Board.

2002. Vilka motiv styr deltagandet i arbetsmarknadspolitiska program? IFAU Rapport no. 2002:9. Uppsala, Sweden: Institute for Labor Market Policy Evaluation.

Holmlund, B., and P. Lundborg. 1988. Unemployment insurance and union wage setting. Scandinavian Journal of Economics 90 (2): 161-72.

Jackman, R., C. Pissarides, and S. Savouri. 1990. Labour market policies and unemployment in the OECD. Economic Policy 5 (2): 449-90.

Jenkins, S., and C. Garcia-Serrano. 2000. Re-employment probabilities for Spanish men: What role does the unemployment benefit system play? ILR Working Paper no. 55. University of Essex, Institute for Labor Research.

Johansson, K. 2001. Do labour market programs affect labour force participation? Swedish Economic Policy Review 8 (2): 215-34.

Johansson, K., and A. Markowski. 1995. Påverkar arbetsmarknadspolitik arbetskraftsdeltagandet? En empirisk studie. Konjunkturläget maj 1995. Specialstudier. Stockholm: Konjunkturinstitutet. 
Katz, L. F. 1996. Wage subsidies for the disadvantaged. NBER Working Paper no. 5679. Cambridge, MA: National Bureau of Economic Research, July.

Katz, L. F., and B. Meyer. 1990. The impact of the potential duration of unemployment benefits on the duration of unemployment. Journal of Public Economics 41 (1): 45-72.

Layard, R., S. Nickell, and R. Jackman. 1991. Unemployment: Macroeconomic performance and the labour market. Oxford: Oxford University Press.

Lindgren, U., and O. Westerlund. 2003. Labour market programmes and geographical mobility: Migration and commuting among programme participants and openly unemployed. IFAU Working Paper no. 2003:6. Uppsala, Sweden: Institute for Labor Market Policy Evaluation.

Martin, J., and D. Grubb. 2001. What works and for whom? A review of OECD countries' experiences with active labour market policies. Swedish Economic Policy Review 8 (2): 9-56.

McCormick, B., and P. Skedinger. 1991. Why do regional unemployment differentials persist? In Essays on wage formation, employment, and unemployment, ed. P. Skedinger. Doctoral thesis, Uppsala University.

Meyer, B. 1990. Unemployment insurance and unemployment spells. Econometrica 58 (4): 757-82.

Moffitt, R. 1985. Unemployment insurance and the distribution of unemployment spells. Journal of Econometrics 28 (1): 85-101.

Nilsson, C. 1995. Den interregionala omflyttningen i Sverige: konsekvenser av arbetsmarknadsläge, arbetsmarknadspolitik och regionala levnadsomkostnader. EFA Rapport no. 33. Stockholm: EFA, Arbetsmarknadsdepartementet.

Organization for Economic Cooperation and Development (OECD). 2004. Benefits and wages 2004: OECD indicators. Paris: OECD.

Regnér, H. 1997. Training at the job and training for a new job: Two Swedish studies. $\mathrm{PhD}$ thesis, Stockholm University.

Sianesi, B. 2001. The Swedish active labour market programmes in the 1990s: Overall effectiveness and differential performance. Swedish Economic Policy Review 8 (2): 133-69.

Stenberg, A. 2003. An evaluation of the adult education initiative relative labour market training. Umeå Economic Studies Working Paper no. 609. Umeå University, Department of Economics.

. 2005. Comprehensive education for the unemployed: Evaluating the effects on unemployment of the adult education initiative in Sweden. Labour: Review of Labour Economics and Industrial Relations 19 (1): 123-46.

Stenberg, A., and O. Westerlund. 2004. Does comprehensive education work for the long-term unemployed? Umeå Economic Studies Working Paper no. 641. Umeå University, Department of Economics.

Storrie, D., and B. Nättorp. 1997. Starthjälp: Geografisk rörlighet 1978-1995 och en utvärdering av starthjälpen. Stockholm: EFA, Arbetsmarknadsdepartementet.

Wadensjö, E. 1993. Arbetsmarknadspolitikens effekter på löner och priser. In SOU 1993:43, Politik mot arbetslöshet. Stockholm: Arbetsmarknadsdepartementet.

Westerlund, O. 1997. Employment opportunities, wages and interregional migration in Sweden 1970-89. Journal of Regional Science 37 (1): 55-73. 1998. Internal gross migration in Sweden: The effects of mobility grants and regional labour market conditions. Labour: Review of Labour Economics and Industrial Relations 12 (2): 363-88.

Widerstedt, B. 1998. Moving or staying? Job mobility as a sorting process. Doctoral thesis, Umeå University. 